\title{
Effect of nutritional intake towards angular cheilitis of orphanage children
}

\author{
Nurdiani Rakhmayanthie*, Erna Herawati*, Dewi Marhaeni Diah Herawati** \\ *Department of Oral Medicine Faculty of Dentistry Universitas Padjadjaran, Indonesia \\ *Department of Medical Nutrition Science Faculty of Medicine Universitas Padjadjaran, Indonesia
}

\begin{abstract}
Introduction: Angular cheilitis is one of the oral manifestations of iron, vitamin $\mathrm{B}_{12}$, and folate deficiency. This manifestation frequently seen in people at first and second decade. The purpose of this study was to obtain the prevalence of angular cheilitis and its classifications related to the nutritional intake level in 6-18 years old children. Methods: This research was a descriptive study with 53 children between 6-18 years old from Muhammadiyah Orphanage Bandung as the samples. The oral cavity was examined clinically and their food consumption in a week was noted in Food Recall 24 hours and Food Frequency Questionnaire (FFQ) in order to measure their nutritional intake level. Results: There are 23 children with angular cheilitis. Thirteen has iron and folate deficiencies, and $87 \%$ has iron, vitamin $B_{12}$, and folate deficiencies. Angular cheilitis types that has been found are Type I (39\%), Type II (48\%) and Type III (13\%). Conclusion: The prevalence of angular cheilitis in 6-18 years old children in Muhammadiyah Orphanage Bandung was moderately high, most of them were having iron, vitamin $B_{12}$, and folate deficiencies. Type II angular cheilitis was the most frequently seen.
\end{abstract}

Keywords: Nutritional intake, angular cheilitis, Orphanage children, vitamin $B_{12}$, folate deficiency

\section{INTRODUCTION}

Human needs a balanced diet for the growth and maintenance of health and life balance. Nutrition is a major factor that supports our optimal body function and health status. ${ }^{1}$ According to the World Health Organization ${ }^{2}$, nutrition is the amount of food received by the body in accordance with the needs of the body that produce energy so that it can perform daily activities.

The adequacy of nutrient intake is the degree of physical needs for energy and nutrients, which we get from food. If the variety of foods to meet the needs of the body, both in quality and quantity, then the body will get nutrition baik ${ }^{3,4}$ circumstances. According $\mathrm{WHO}^{2}$, adequate nutrition is one of the main keys to getting a good health status. Lack of nutrition when there is a cellular imbalance between supply of food was obtained to form the body's energy needs to support the growth, health maintenance, and physiological functions. ${ }^{5}$

Malnutrition in children may causes disturbances of children growth. During childhood, giving poor nutrition can result in the troubled growth process of children and cause various 
diseases associated with nutritional deficiencies. ${ }^{6}$ Examination of the oral cavity and perioral performed by a dentist can provide information on the nutritional state of the patient, even a dentist may be the first to find clinical signs of malnutrition. The dentist should know the oral manifestations of malnutrition, one of which may be either angular cheilitis caused by a nutritional deficiency of iron, vitamin $B_{12}$, and folic acid. ${ }^{7}$ Angular cheilitis is an inflammatory state in the corner of the lips which may arise bilateral or unilateral. This situation is accompanied by pain, discomfort, sometimes to bleed, and it can interfere with chewing and speaking..$^{8-11}$

Angular cheilitis often seen on children and teenagers. Etiological factor of angular cheilitis in children may also vary, which in most cases is caused by nutritional deficiencies, especially iron, vitamin $B_{12}$, and folic acid. ${ }^{7,9}$ Angular cheilitis associated with lack of nutrition is often encountered in the first and second decade of life. $^{12}$

Some reports indicate that there is a link between nutritional deficiency with angular cheilitis. Research conducted by Zaidan in Baghdad $35.3 \%$ of 82 patients affected by angular cheilitis had iron deficiency. ${ }^{13}$ Research conducted by Lopez in the six orphanages in Medan in children 6-12 years of age showed that children with nutritional status were less likely to suffer angular cheilitis 1.96 times greater than children who have a good nutritional status. ${ }^{12}$

The orphanage is an institution that generally have a limited economical condition, as based on the financial aspects, orphanages generally only relies on donors and social services. The financial limitations may cause the children living in orphanages generally have less intake of carbohydrates, proteins, fats, vitamins, and minerals, because of the variety of food is limited, and that will have implications on the state of child nutrition. Children living in an orphanage is a group of children that more likely to have a nutritional deficiency. ${ }^{14}$

The purpose of this study was to obtain information on the prevalence and classification of angular cheilitis associated with nutrient intake level, particularly iron, vitamin $B_{12}$, and folic acid in children aged 6-18 years at the Muhammadiyah Orphanage Bandung.

\section{METHODS}

The method of this research was a descriptive survey using cross sectional approach, the data collection were done at one time simultaneously. In this study, data collection was done from the month of May to June 2013. The sample is in the form of total sampling, as all of the childrens are within the age range of 6-18 years old who has lived in the orphanage at least two years; was willing to be examined, interviewed and observed about his/her diet. Children who refuse to participate or suffer from angular cheilitis due to trauma were excluded from the sample.

Research carried out in several phases. First phase, researchers examined the corners of the mouth clinically of each respondent one by one to see whether there was any angular cheilitis lesions, characterized by erythema, fissures, crusting, or ulcers on the corner of his mouth. The second phase was collecting data of the food consumption survey, using 24-hour Food Recall and Food Frequency Questionnaire (FFQ), which was filled out by doing interviews and direct observation. Observations were recorded as follows: the diet of each subject for one week; types of food consumed by each subject of study in the morning, noon, and night, expressed in URT (Ukuran Rumah Tangga/household size) such as spoons, cups, plates, and others; The researchers used food models so that the food portions obtained by each research subject is illustrated with greater ease; researchers convert data expressed in units of URT into grams using guidelines from Daftar Bahan Makanan Penukar/ List of Substitution Food (DBMP).

Food consumption survey was done using a 24-hour Food Recall and Food Frequency Questionnaire (FFQ) was calculated by the conversion of consumption per day multiplied by the amount consumed a meal in grams to get a number of nutrient intake. And then we analyzed that data using Nutrisurvey program to convert the data into units of kilocalories (kcal). The amount of each nutrient compared to the Recommended Dietary Allowance/RDA or Angka Kecukupan Gizi (AKG) Kemenkes RI 2004 which is set at Nutrisurvey program. Then the nutrient intake was recorded on the data sheet of each respondent. Research data presented in tabular 
form and the percentage distribution, as well as a descriptive narrative.

\section{RESULTS}

Samples numbered were 53 people. Interviews and direct observation of subjects diet conducted to know the description of nutrient intake for one week through two questionnaires, namely the 24-hour Food Recall and Food Frequency Questionnaire. The results of the 24-hour Food Recall and Food Frequency Questionnaire can determine dietary intake of research subjects, which are then processed using Nutrisurvey. The level of nutrient intake that is recorded was iron, vitamin $B_{12}$, and folic acid.
Table 1 below shows the mean intake of iron, vitamin $B_{12}$, and folic acid obtained an then compared with recommended Nutrition Adequacy Rate/Angka Kecukupan Gizi (AKG) for children aged 6-18 years. The average intake of iron, vitamin $B_{12}$, and folic acid of the subjects aged 6-18 years in the Muhammadiyah Orphanage Bandung are still in the poor category (Table 1).

Table 2 shows that the subjects have deficiency of more than one nutrients. $100 \%$ of children lack of iron and folic acid, whereas vitamin $B_{12}$ intake is sufficient in $62 \%$ of children. It can be said that the subjects are having deficiency of more than one nutrients. A total of 33 children who had sufficient intake of vitamin $B_{12}$ are also having a deficiency in iron and folic acid, while

Table 1. Average intake of Iron, Vitamin $\mathrm{B}_{12}$, and Folic Acid Per Day of Children in Muhammadiyah Orphanage Bandung Compared with AKG. $(n=53)$.

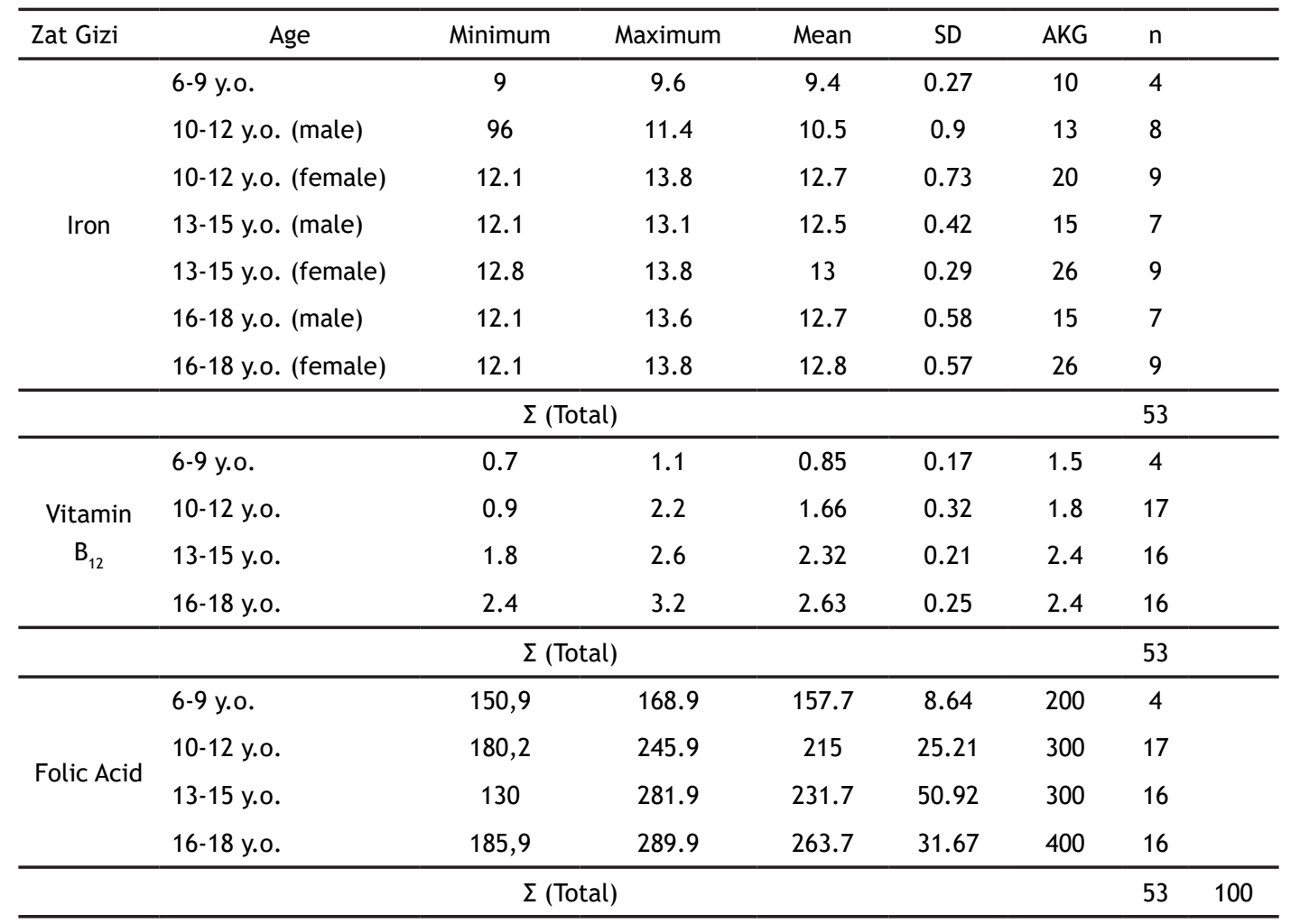

Table 2. Overview of the Iron, vitamin B12 and folic acid intake level of the children in Muhammadiyah Orphanage Bandung age 6-18 years.

\begin{tabular}{lcccccc}
\hline \multicolumn{1}{c}{ Nutrients } & \multicolumn{2}{c}{ Adequate } & \multicolumn{2}{c}{ Deficient } & \multicolumn{2}{c}{$\boldsymbol{\Sigma}$} \\
$\quad(\mathbf{n}=53)$ & $\mathbf{n}$ & $\%$ & $\mathbf{n}$ & $\%$ & $\mathbf{n}$ & $\%$ \\
\hline Iron & 0 & 0 & 53 & 100 & 53 & 100 \\
Vitamin $\mathrm{B}_{12}$ & 33 & 62 & 20 & 38 & 53 & 100 \\
Folic acid & 0 & 0 & 53 & 100 & 53 & 100 \\
\hline
\end{tabular}


Table 3. Percentage of angular cheilitis in Muhammadiyah Orphanage Bandung Children

\begin{tabular}{lllllll}
\hline Angular & \multicolumn{2}{l}{ Positive } & \multicolumn{2}{l}{ Negative } & \multicolumn{2}{l}{$\Sigma$} \\
\cline { 2 - 7 } Cheilitis & $\mathrm{n}$ & Percentage & $\mathrm{n}$ & Percentage & Sum & Percentage \\
$(\mathrm{n}=53)$ & 23 & $43 \%$ & 30 & $57 \%$ & 53 & $100 \%$ \\
\hline
\end{tabular}

Table 4. Distribution of angular cheilitis by sex, age, and education of Muhammadiyah Orphanage Bandung Children with angular cheilitis.

\begin{tabular}{llcc}
\hline \multirow{2}{*}{ Categories $(\mathrm{n}=23)$} & \multicolumn{2}{c}{ Angular cheilitis } \\
\cline { 2 - 4 } & $\mathrm{n}$ & Percentage \\
\hline Sex & Male & 16 & $70 \%$ \\
- & Female & 7 & $30 \%$ \\
$\Sigma$ & & 23 & $100 \%$ \\
Age & & & \\
- & $6-9$ years old & 4 & $17 \%$ \\
- & $10-12$ years old & 11 & $48 \%$ \\
- & $13-15$ years old & 6 & $26 \%$ \\
- & $16-18$ years old & 2 & $9 \%$ \\
$\Sigma$ & & 23 & $100 \%$ \\
Education & & \\
- & Elementary School & 13 & $57 \%$ \\
- & Junior High School & 8 & $35 \%$ \\
- & Senior High School & 2 & $8 \%$ \\
$\Sigma$ & & 23 & $100 \%$ \\
\hline
\end{tabular}

Table 5. Overview of angular cheilitis and nutrient intake levels.

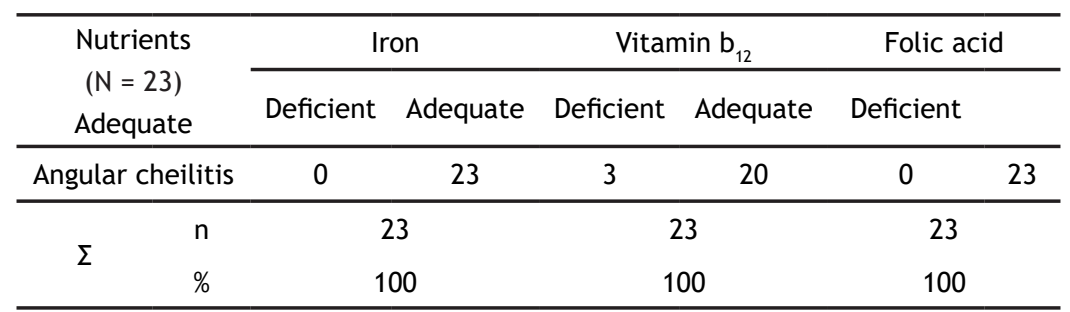
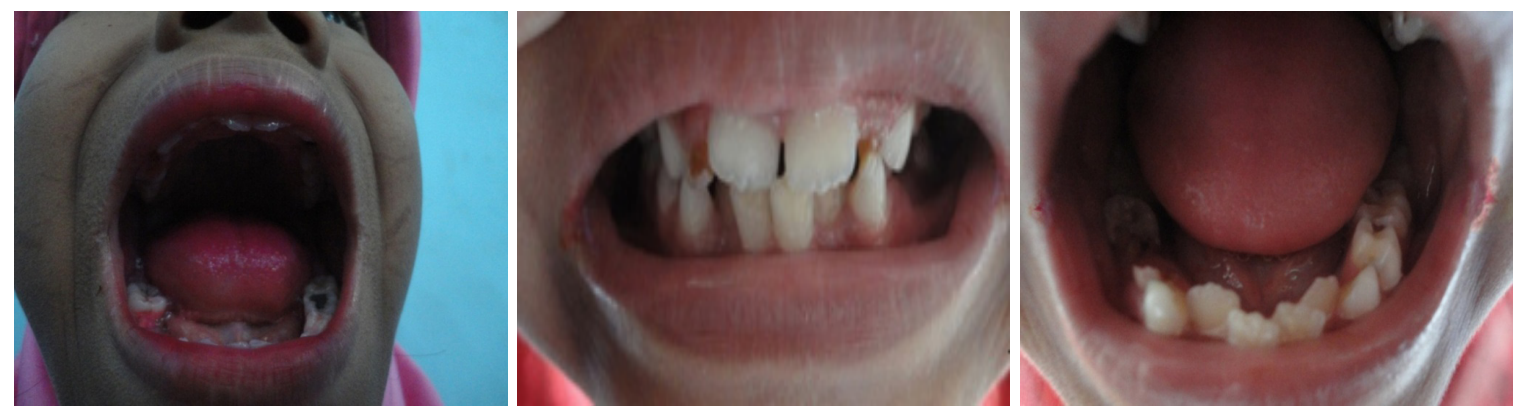

Figure 1. a) Angular cheilitis Type I in patients 11 years old; b) Angular cheilitis Type II in patients 9 years old; and c) Angular cheilitis Type III in patients 8 years old.

20 people have iron deficiency, vitamin $B_{12}$, and folic acid.

Table 3 below shows the percentage of angular cheilitis that were found from the overall sample. Angular cheilitis examination among children in Muhammadiyah Orphanage Bandung was categorized high rate, 23 of $53(43 \%)$ children showed angular cheilitis.

Table 4 shows the frequency distribution by sex, age and education of of Muhammadiyah 
Orphanage Bandung Children suffer from Angular Cheilitis. The information in Table 5 shows that in this study 23 of the children that were suffered from angular cheilitis have a deficiency of more than one nutrient. Figure 1. shows many types of Angular cheilitis, include: Type I in patients 11 years old (Fig. 1a); Type II in patients 9 years old (Fig. 1b); and Type III in patients 8 years old (Fig. 1c).

\section{DISCUSSION}

According to WHO, approximately 150 million (26.7\%) of children under age 5 in some developing countries in the world were malnourished by weight at his age. These nutritional deficiencies occur due to lacking of the intake of nutrients, especially for the needs of growing children. ${ }^{12}$ Iron, vitamin $B_{12}$, and folic acid are some of the nutrients needed to assist in the growth and development of children. Iron deficiency anemia is the most frequent type of anemia occurs. The percentage is about $30 \%$ of the world's population, 500 million cases worldwide. ${ }^{7}$ Megaloblastic anemia reported for up to $75 \%$ of individuals who are deficient in vitamin $B_{12}$ and folic acid. In South Africa $90 \%$ of women giving birth and breastfeeding suffer from a lack of folic acid..$^{15}$ These descriptions indicate that the case of iron deficiency, vitamin $B_{12}$, and folic acid is quite frequent.

Observing the consumption patterns of children depicted in the interview FFQ, some foods that has high value iron, vitamin $B_{12}$, and folic acid are rarely consumed. According to researchers, it is due to lack of interest and awareness of children to high in iron, vitamin $B_{12}$, and folic acid foods, such as liver, egg yolk, and fish. Many children in 6-12 years old, looks like picking only preferred foods daily. In this research, a total of 33 subjects (62\%) have sufficient daily intake of vitamin $B_{12}$ in the age range 16-18 years. It shows that the orphanage in this group age already understand the type of food to be consumed and capable enough to provide food containing vitamin $B_{12}$, for example, are often consumed chicken meat and cow's milk.

In contrast to the intake of iron and folic acid were found lacking in all research subjects, when compared with the AKG (Recommended Dietary Allowance/RDA). Vitamin $B_{12}$ is only 1.8 to $2.4 \mathrm{mg}$ per day for children aged 6-18 years and iron is needed in large enough quantities ie 10-26 mg per day for children aged 6-18 years, similarly with folic acid, which is $200-400 \mathrm{mg}$ per day. According to our research team observations, the orphanage can already provide some foodstuffs containing iron and folic acid, such as beef, chicken, spinach, vegetable kale, tofu, tempeh, beans, bananas, orange, and milk, although according to FFQ results, some of which are still in a rare category. The amount RDA for iron and folic acid, the quantity of food containing iron and folic acid should be adjusted, and the Orphanage need to increase the quantity of food that is high in iron and folic acid, in order to achieve the RDA.

According to Scully ${ }^{10}$, age is not a risk factor of angular cheilitis, the highest incidence of angular cheilitis is quite often found on the first and second decade of life ${ }^{12}$. In this study, the age of 6-18 years was such a broad in age range, for each age group are likely to suffered from angular cheilitis if there were causes and predisposing factors. However, in the terms of nutritional factors, children in the 6-12 years age often have a tendency to eat more snacks that are less nutritious $^{6}$, so that can lead to angular cheilitis.

Iron, vitamin $\mathrm{B}_{12}$, and folic acid deficiency may show some clinical manifestations, one of which may be either angular cheilitis. Angular cheilitis can occur to everyone and is not affected by the type of gender. ${ }^{10}$ Angular cheilitis may provide varies clinical picture depending on the severity of the angular cheilitis itself. Clinical examination noting the characteristics that distinguish the severity of angular cheilitis according Warnakulasuriya et al. ${ }^{16}$ namely Type I (mild), Type II (moderate), and Type III (severe) 16. In Table 5 below presenting the angular cheilitis Type II is a type of angular cheilitis that mostly seen, counted $48 \%$, followed by Type I (39\%) and type III (13\%).

It was found three children suffering from angular cheilitis, they were sufficient with intake of vitamin $B_{12}$. Angular cheilitis were also found in 20 children with less intake of vitamin $B_{12}$. Angular cheilitis clinical signs were not seen in 30 children with the less sufficient intake of iron and folic acid but with an adequate intake of vitamin $B_{12}$. Observing this, it can be said that the effect of vitamin $B_{12}$ is large enough to cause the onset of angular cheilitis. 
Vitamin $B_{12}$ has a very large role in the process of DNA synthesis, as without vitamin $\mathrm{B}_{12}$, folic acid can not be transformed into its active form so that the group of 5-methyl tetrahydrofolate can not help the process of formation of methylcobalamin which will give the group methyl to the homocysteine for the methionine synthase, which form methionine and tetrahidrofolate. ${ }^{17}$ Tetrahydrofolate is a precursor for folate cofactors required in the synthesis of DNA cell to form purine and timin. ${ }^{18}$ Similarly, in the formation of blood cells, megaloblastic anemia due to vitamin $B_{12}$ deficiency lies in the role of $B_{12}$ in a reaction that is influenced by the this cycle of methionine synthase. ${ }^{17}$

The process of DNA synthesis cells require vitamin $B_{12}$ and folic acid. Vitamin $B_{12}$ functions as a cofactor in enzymatic reactions required in the synthesis of DNA. Folic acid has an important role formation reaction of purine and thymine, which are critical components forming the DNA. ${ }^{18-}$ 20 If there is any deficiency of vitamin $B_{12}$, folic acid, or both, the process of DNA synthesis would be disturbed, resulting in an interruption in the process of mitosis so that the cells do not mature and the formed cell may be dysfunctional. ${ }^{19,20}$ These cells are fragile, easily broken and have a shorter life than normal cells. ${ }^{18}$ Changes will clearly be seen easily on cells that divide rapidly, such as the cells in the bone marrow, will be an interruption in the process of hematopoiesis, and led to the interrupted formation of red blood cells with the characteristics of macrocytic cells with an oval shape that is irregular indicating the cells are not matured. ${ }^{19,20}$

The cells of the skin and mucosal are regenerated quicker than other cells ${ }^{21}$, so the signs of deficiency intake of iron, vitamin $B_{12}$, and folic acid can be seen also in the oral cavity. Research conducted by Zaidan in Baghdad ${ }^{13}$ showed that $35.3 \%$ of 82 patients affected by angular cheilitis have iron deficiency anemia. There are no research data that specifically describes the angular cheilitis with a deficiency of vitamin $B_{12}$ and folic acid, but the clinical examination which researchers observe, seen some signs of deficiency of these nutrients in the oral cavity, including the tongue that looked smooth with a reddish color. Clinical signs appear on the subject of these studies were looks not too bad and difficult to distinguish from normal, but it was thought to be a clinical sign of a lack in vitamin $B_{12}$ and folic acid daily intake.

The results also need to be examined further, to have more accurate research about nutritional value, the examination of iron, vitamin $B_{12}$, and folic acid in blood serum, as well as its relationship with the occurrence of angular cheilitis. Also, from this study were expected to be a consideration to improve the nutritional intake of children by providing education about nutritious foods, as well as improvin the quality and quantity of food that is high in iron, vitamin $B_{12}$ and folic acid. Based on this research results, we hope that Indonesia which is a developing country that still have nutritional problems will do more fight for health policy for the children's health development in Indonesia.

\section{CONCLUSION}

It can be concluded that the level of nutritional intake in children aged 6-18years of Muhammadiyah Orphanage Bandung were still in the poor category, with some combination of deficiency in nutritional intake of iron, vitamin $B_{12}$, and folic acid. The prevalence of angular cheilitis were found $43 \%$ and angular cheilitis lesions Type II was the most commonly type in this study.

\section{REFERENCES}

1. Smolin LA, Grosvenor MB. Basic nutrition. New York: Chelsea House, Infobase Publishing; 2005. p. 1-3.

2. WHO. Oral health. 2012. [cited 2013 Jan 15]. Available from: http://www.who.int/ mediacentre/factsheets/fs $318 /$ en/index. html.

3. Braun CA, Anderson CM. Pathophysiology: functional alterations in human health. Philadelphia: Lippincott Williams \& Wilkins. 2007. p. 155.

4. Brunton LL, Lazo JS, Parker KL. Goodman \& Gilman's: The pharmacological basis of therapeutics. $11^{\text {th }}$ ed. New York: McGraw Hill Medical Publishing; 2006. p. 1442-6.

5. Scheinfield NS. Protein-energy malnutrition. 2013. [cited 2013 Mar 5]. Available from: http://emedicine.medscape.com/ article/1104623-overview. 
6. Adriani M, Wirjatmadi M. Peranan gizi dalam siklus kehidupan. Jakarta: Kencana prenada media group; 2012. p. 246-347.

7. Greenberg MS, Glick M, Ship JA. Burket's oral medicine: diagnosis \& treatment. Hamilton: BC Decker Inc.; 2008. p. 97-98, 431.

8. Regezi JA, Sciubba JJ, Jordan RCK. Regezi: oral pathology, clinical pathologic correlations $5^{\text {th }}$ ed. Philadelphia: Elsevier Inc.; 2008. p. 338-45, 1218.

9. Cameron N, Bogin B. Human growth and development. San Diego: Elsevier Inc.; 2012. p. 124.

10. Scully C. Oral and maxillofacial medicine, the basis of diagnosis and treatment. Toronto: Wright; 2008. p. 147-9.

11. Chaudhary M, Chaudhary SD. Essentials of pediatric oral pathology. India: Jaypee Medical Publishers; 2011. p. 167.

12. Lubis $S$. Status gizi dengan keilitis angularis pada anak umur 6-12 tahun di enam panti asuhan di Kota Madya Medan. Dentika Dent J 2006;11(2):117-21.

13. Zaidan TF. Angular cheilitis and iron deficiency anemia. MDJ 2008;(1):37-40.

14. Susanti DA. KTI: Perbedaan asupan energi, protein, dan status gizi pada remaja panti asuhan dan pondok pesantren. J Media Medika
Muda 2012;1(1) (E-Journal). [cited 2013 Feb 10]. Available from: http://ejournal-s1.undip. ac.id/index.php/medico/issue/view/103.

15. Tangkilisan HA, Rumbajan P. Defisiensi asam folat. Sari Pediatri 2002;4(1):21-5.

16. Warnakulasuriya KAAS, Samaranayake LP, Peiris JSM. Angular cheilitis in a group of Sri Lankan adults: a clinical and microbiologic study. J Oral Pathol Med 1991;20:172-5.

17. Almatsier S. Prinsip dasar ilmu gizi. Jakarta: Gramedia Pustaka Utama; 2005. p. 3, 208-17, 249-57.

18. Guyton AC, Hall JE. Textbook of medical physiology. $11^{\text {th }}$ ed. Philadelphia: Elsevier Inc.; 2006. p. 423-26, 874-7.

19. Yagiela JA, Dowd FJ, Johnson BS, Mariotti AJ, Neidle EA. Pharmacology and theurapeutics for dentistry. St. Louis: Mosby, Elsevier Inc. 2004. p. 483-95.

20. Katzung BG. Basic and clinical pharmacology $6^{\text {th }}$ ed. Farmakologi Fakultas Kedokteran Universitas Sriwijaya, transl. Jakarta: EGC; Alling $\mathrm{CCl}$, Alling RD. Indications for management of impacted teeth 2010. p. 51323.

21. Cummings MR. Human heredity: principles and issues. Belmont, USA: Brooks/Cole Cengage Learning. 2011. p. 21. 